\title{
Exploring the Function of Dhihn/Zihin (Cognitive Link) in Majāz in Islamic Legal Theory ${ }^{*}$
}

\section{İslam Hukuku Teorisinde Majāz'da Dhihn / Zihin (Bilişsel Bağlantı) İşlevini İncelemek}

\author{
Hakime Reyyan Yaşar**
}

\begin{abstract}
Simon Udo and Michiel Leezenberg point to the cognitive traces in the works of 'Abd al-Qāhir al-Jurjānī (d. 1078), named Asrār al-Balāgha and Dalä'il al-i'jāz. However, neither Simon nor Leezenberg provide an insight whether these traces can be found in other classical sources, where majāz and isti'āra are discussed.

This paper argues that Simon's and Leezenberg's argument that the awareness of the cognitive elements in the classical Islamic approach to majāz and isti'āra cannot be reduced in 'Abd al-Qāhir al-Jurjānī's works. Rather, that the Hanafï

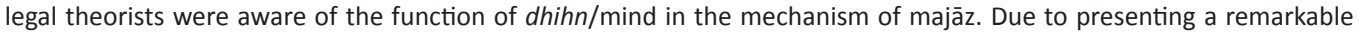
theoretical examination of the tropes and metaphors, $13^{\text {th }}$ and $14^{\text {th }}$ century Hanafi ușül al-figh sources are chosen. To clarify my argument, I will mainly focus on the analysis of the terminology, which expounds the relationship between majāz and mind: Such as, ittișāl (ilink/connection), dhihn (mind,) mahal (space/domain).
\end{abstract}

\section{Keywords}

Ușūl al-fiqh, Majāz, Isti’āra, Ittișāl, Dhihn

\section{Öz}

Simon Udo ve Michiel Leezenberg, Abd el-Kahir el-Cürcani'nin Esrar el-Belağa ve Delailü'l-i̇caz adlı eserlerinin mecaz ve istiare bahsinde bilişsel dil bilimin izlerinin bulunduğunu iddia etmişlerdir. Ancak, ne Simon ne de Leezenberg iddia ettikleri bu izin, mecaz ve istiare konusuna yer veren başka klasik eserlerde bulunup bulunmadığına değinmez. Bu çalışma, Simon ve Leezenberg'un iddia ettiği bilişsel izlerin sadece Abd el-Kahir el-Cürcani'nin eserlerine hasredilemeyeceğini, aksine Hanefi usûlcülerin zihin ve mecaz ilişkinden haberdar olduklarını ortaya koymayı hedeflemektedir. Çalışmanın savını sınırlandırmak için ve tartışmaya sundukları önemli kavramlar ve örnekler sebebiyle ağırlıklı olarak 13. ve 14. yüzyıl Hanefi usul eserlerinden yararlanılmıştır. Bu çalışmada Hanefi usûlcülerin mecaz ile zihin arasındaki ilişkiyi açıklamak için kullandıkları ittisal, zihin ve mahal kavramları ele alınacaktır.

\section{Anahtar Kelimeler}

Fıkıh usulü, Mecaz, İstiare, İttisal, Zihin

\footnotetext{
* This article is the expanded and additive version of the paper previously presented at BRAIS Conference 2017.

**Corresponding Author: Hakime Reyyan Yaşar (Dr.), Mardin Artuklu University, Faculty of Theology, Department of Islamic Law, Mardin, Turkey. E-mail: hakimeyasar@artuklu.edu.tr ORCID: 0000-0003-4873-2246
}

To cite this article: Yaşar, Reyyan Hakime. "Exploring the Function of Dhihn/Zihin (Cognitive Link) in Majāz in Islamic Legal Theory." darulfunun ilahiyat 31, 1 (2020): 1-21. https://doi.org/10.26650/di.2020.31.1.0053 


\section{Introduction}

Modern scholarship on Arabic linguistics and philosophy of language has overlooked the discussions in ușul al-fiqh (legal theory for Islamic law), in Vishanhoff's words: "has focused mostly on non-linguistic dimensions of legal theory" ${ }^{~}$. In effect, there was a reciprocal contribution between Islamic legal theory and Arabo-Islamic linguistics, and an exchange of conceptualisation, terminology, and reasoning since the post-formative period of Islamic law. ${ }^{2}$ One of the important junction points between these disciplines is majāz (figurative speech, non-literal meaning of a word) that has received limited scholarly interest compared to what it deserves. Udo Simon and Michiel Leezenberg's two studies on majāz attract attention in terms of pointing to how maja $z$ is approached in classic Arabic linguistics. In relation to the contemporary discussions about metaphor, they argue that majāz in classical Arabic linguistics was discussed significantly related to the mind. Relying on this, this article argues that not only linguists but also legal theorists were conscious of the constitutive function of mind in majāz.

In the Muslim world, from the ninth century onwards, works were composed to explore the figurative characteristics of the Arabic language. Within this period, the Aristotelian model of metaphor took also the attention of the Muslim philosophers and linguists. The Muslim scholars did not take the theory of Aristotle for metaphor as bare fact. ${ }^{3}$ But, they developed their account of types of majāz; including metaphor based on Aristotelian metaphor. ${ }^{4}$ In comparison to Aristotle's metaphor, majāz has undergone a distinguished development process in Islamic intellectual history. $M a j \bar{a} z$ as a linguistic concept was not confined to the province of rhetoric or to the aesthetic evaluation of language, but rather, to understand the Qur'ān. Thus, majāz has been engaged in profound theological, philosophical, and legal debates as a consequence of what gives the divine text (the Qur'ān) and human language ${ }^{5}$. Over the course of this evolution, majāz became a significant subject for ușül al-fiqh.

1 David R. Vishanoff, The Formation of Islamic Hermeneutics How Sunni Legal Theorist Imagined a Revealed Law (New Haven, Connecticut: American Oriental Society, 2011), xiii.

2 Nora Kalbarczyk, Sprachphilosophie und der Islamischen Rechtstheorie: Zu avicennischen Klasifikation der Bezeichnung bei Faḥr ad-dīn ar-Rāzī (Leiden, Boston: Brill, 2018), 1-2.

3 Kamal Abu Deeb, “Al-Jurjānī’s Classification of Istiara with Special Reference to Aristotle's Classification of Metaphor,” Journal of Arabic Literature, no. 2 (1971): 48, 62.

4 Balqis Al-Karaki, "Dissimilar Premises, Similar Conclusions: On the Partial Rationality of Metaphor- a Comparative Study,” Journal of Near Eastern Studies 70, no. 1 (April 2011): 89.

5 Hadith became later a source for grammatic reasoning (Simona Oliveri, "Early Arabic grammar: sources and codification," in Dal Medio all'Estremo Oriente, eds. Marina Miranda and Raffaele Torella e Mario Casari (Roma: Carocci Editore, 2018), 63). 
Another, fundamental difference in discussing the equivalent of isti 'àra (metaphor) and majāa (figurative speech) stems from how Muslim intellectuals expound this linguistic content based on the relationship between lafẓ/vocal/form/ utterance and $m a$ ' $n \bar{a} /$ meaning/content/idea. ${ }^{6}$ As Adamson and Key put in words, this pairing "was the predominant model used to relate mental content to linguistic content, and it was in play across all available genres, from poetry to exegetical hermeneutics and legal theory". ${ }^{7}$ As a result, this model became a theory in the philosophy of Arabic language. ${ }^{8}$

Related to this model that used to relate words to mental content, Simon and Leezenberg argue that in the $11^{\text {th }}$ century, 'Abd al-Qāhir al-Jurjānī (d. 471 /1078) referred to a specific relationship between figurative language and mental content - both prefer to name this content "cognition". Simon and Leezenberg direct that some cognitive elements can be found in the theory of majāz in al-Jurjānī's books titled Asrär al-Balägha and Dalä'il al-i 'jāzz. ${ }^{9}$ Previously Simon and Leezenberg, Modaressi mentioned that al-Jurjānī and al-Sakkākī (d. 626/1229) explained how isti ' $\bar{a} r a$ indeed is reflected in the mind of the speaker. ${ }^{10}$ Modaressi focuses on explaining the concept of majazz, therefore there is not much information given on how mind/cognition functions in the process of majäz.

I am aware that Modaressi's, Simon's and Leezenberg's arguments are embryonic. Their claim requires more explication than what they point to. Particularly, qualification is needed on what Simon and Leezenberg mean regarding cognition and cognitive elements in maja $z$. The borders of the definition of cognition have changed with the contribution of cognitive linguistics and scientists. ${ }^{11}$ On the philosophical level, al-Karaki approaches with caution on comparing cognition in traditional and contemporary philosophy of language theories. She argues that

6 Ibrahim Özdemir, İslam Düşüncesinde Dil ve Varlık Vaz’ İlminin Temel Meseleleri (Istanbul: İz Yayınevi, 2006), 37; Lara Harb, "Form, Content, and the Inimitability of the Qur'an in 'Abd al-Qahir al-Jurjān̄̄'s Works,” Middle Eastern Literatures 18, no. 3 (2015): 301-16.

7 Peter Adamson and Alexander Key, "Philosophy of Language in the Medieval Arabic Tradition," in Linguistic Content: New Essays on the History of Philosophy of Language, eds. Margaret Camoran and Robert J. Stainton (Oxford: Oxford University Press, 2015), 74.

8 Adamson and Key, "Philosophy of Language," 75-77.

9 Udo Simon, "Majāz", Encyclopaedia of Arabic Language and Linguistics (Leiden: Brill, 2008), 118; Udo Simon, "Isti 'āra", Encyclopaedia of Arabic Language and Linguistics (Leiden: Brill, 2008), 442; Michiel Leezenberg, Contexts of Metaphor (1st Edition, Oxford: Elsevier Science Ltd, 2001), 51, 56.

10 Hosseini Modaressi, "Some Recent Analyses of the Concept of majāz in Islamic Jurisprudence," Journal of the American Oriental Society 106, no. 4 (Oct.-Dec. 1986): 788.

11 Al-Karaki, "Dissimilar Premises," 83. 
this discussion requires sufficient evidence or bases for their comparability. ${ }^{12}$ In addition to al-Karaki, in his book named Sprache, Handlung und Norm, Tahsin Görgün argues that maybe not comparing but that many discussions and subjects in the classical Islamic intellectual history (Geistesgeschichte) can be expounded and compassed with the contribution of contemporary linguistic theories and philosophy of language. ${ }^{13}$

Even though the differences in the traditional and contemporary understanding of metaphor, and in understanding and conceptualizing $\mathrm{dhihn} / \mathrm{mind}$ or cognition (in the simplest form), I believe that there are valid reasons in the Arabo-Islamic literature for searching for how dhihn was conceptualised ${ }^{14}$. To discuss my argument on solid ground, I mainly focus on the analysis of metaphors and the terminology, which expounds the relationship between isti 'âra and mind/dhihn in post-formative Hanafì ușūl. The terms that I put under scope are ittișāl (link) connection), șura (image), ma 'nā (abstract, meaning, content), dhihn (mind/ cognition), and mahal (space, domain). These terms grant us an insight into how the Hanafì legal theorists understand the mechanism of majāz. In this regard, this article aims to be a preliminary to an intriguing discussion on the relation between majāz /isti 'āra and mind in Hanafì ușūl al-fiqh .

To confine the study, I will mostly rely on Ușūl al-Sarakhsī by al-Sarakhsī (d. 1090), Sharh al-Manār wa Hawashiyya min 'ilm al-ușūl by Ibn Malak (d. 1418) and Al-Kāfì sharh al-Bazdawī by al-Sighnāqī (d. 1314), due to presenting remarkable theoretical examination of majāz. The confined nature of this article, which only focuses on a few Hanafi sources, should not delimitate the borders of this discussion. For instance, Jāhiz (d. 869) claims that metaphor is the core of the language- similar to Lakoff. ${ }^{15}$ Or, Taftāzānī (d. 1390) or Sayyid Sharīf al-Jurjānī (d. 1413) suggests that if there is a shared property between the two things (two domains), mind/dhihn surely creates a relation between them. ${ }^{16}$

12 Al-Karaki, "Dissimilar Premises," 82.

13 Tahsin Görgün, Sprache, Handlung und Norm: Eine Untersuchung zu "Ușūl al-Fiqh" und "Kitāb as-Siyar" des Šams al-A 'imma Muhammad b. Abī Sahl Ahmad as-Sarahsi (1009-1090 n. C.) (Istanbul: İSAM Yayınevi, 1998), i.

14 Al-Karaki, "Dissimilar Premises,” 81-82, 89; Zeynep Gemuhluoğlu, “İslâm Düşüncesine Özgü Bir Poetikadan Söz Edilebilir mi?: İlk Dönem Kelâm ve Dil Âlimlerinde Din Dili-Mecâz/ŞiirMecâz İlişkisi Üzerine Bir İnceleme,” M. Ü. İlahiyat Fakültesi Dergisi 36, no.1 (2009): 122-23.

15 Mohammad Salama, The Qur'an and Modern Literary Criticism: From Taha to Nasr (London: Bloomsbury Academic/ Bloomsbury Publishing, 2018), 106.

16 Ömer Türker, "Seyyid Şerif Cürcani'nin Tevil Anlayışı: Yorumun Metafizik, Mantıki ve Dilbilimsel Temelleri" (PhD diss., University of Marmara, 2006), 182; Modaressi, "Some Recent Analyses," 788. 
As a final note, the Hanafî legal scholars sometimes called isti 'âra "majāz". The reason for this usage is elucidated below. To avoid any intricacy and not to drift away from the focal point of this study, in this article, I will follow the use of the ușülis and will not engage in the identification process of majāz and isti 'àra in the current texts; and sometimes I will call both of them metaphor.

\section{A Brief History on the Theory of Majāz}

In metaphor studies, Aristotle's theory of metaphor (350 BC) is widely accepted as the start of discussing figurative use in the language. Aristotle in his definition describes the mechanism of metaphor by paying attention to the categories of metaphor and to the relation between genus and species, and analogy:

" a 'metaphorical term' involves the transferred use of a term that properly belongs to something else; the transference can be from genus to species, from species to genus, from species to species, or analogical." 17

Although, Aristotle's theory of metaphor profoundly impacts the development of the classical art of poetics and rhetoric, his theory did not receive a major challenge from western philosophers, during the post-Aristotelian period and Middle Ages in Christian Europe. Thereupon, the discussions were mainly unattended for centuries. ${ }^{18}$ In the meantime, starting from the $9^{\text {th }}$ century in the Arabo-Islamic literature, maj $\bar{a} z$ (including metaphor as the sub-category of majāz) was widely discussed by Arab and non-Arab philosophers, theologians, linguists and legal theorists.

The pre-Islamic Arab community (Ahl al- 'arab) had a syntactic sense of figurative language and had their own terms for it such as mathal (tamthil- analogy, similaritybased metaphors) and tashbīh (similar to isti 'âra [metaphor]). ${ }^{19}$ After the revelation of the Qur'ann and with the rise of the Islamic intellectual activity, the theological and literary discussions around the concept of majāz were developed. The theological debates on the existence of maja $z$ in the language were primarily motivated by an attempt to gain an accurate understanding of the verses in the Qur'ān (Q 12:2; 43:3; 20: 5); for instance, God's hand (Q 5: 64; 48: 10). Specifically, the anthropomorphic and figurative features of some ayah in the Qur'ān provoked theological debates mainly between the two well-known theological schools- Mu'tazilites and Ash'arites. ${ }^{20}$

17 Samuel R. Levin, “Aristotle's Theory of Metaphor,” Philosophy \& Rhetoric 15, no. 1 (Winter 1982): 24.

18 Raymond W. Gibbs, "When is Metaphor? The Idea of Understanding in Theories of Metaphor," Poetics Today, Aspects of Metaphor Comprehension 13, no. 4 (Winter 1992): 575.

19 Wolfhart Heinrichs, "On the figurative (majâz) in Muslim interpretation and legal hermeneutics," in Interpreting Scriptures in Judaism, Christianity and Islam: Overlapping Inquiries, eds. Mordechai Z. Cohen and Adele Berlin (Cambridge: Cambridge University Press, 2016), 265. 
Meanwhile, this process should not make one think that the theory of majāz was developed purely from a religious impetus. As argued by Heinrichs, the subject of majāz has a non-religious side (the philological aspect). ${ }^{21}$ For Arab scholars, majāz was a linguistic concept to be taken into consideration with the concern to protect the language of the linguistic community (Sprachgemeinschaft). ${ }^{22}$ Likewise, Mustafa Shah voices that even though majāz as a subject of debate was motivated by theological questions, this did not prevent majāz also from becoming a mere matter of linguistics. ${ }^{23}$

The earliest appearance of the word majāz can be found in the work of the Basran philologist, Abū 'Ubayda (d. 824-5), in his book Majāz al-Qur 'ān. ${ }^{24}$ In the introduction of this work, there are examinations of 38 instances of majāz from the Qur'ān ${ }^{25}$ without mentioning haqīqa as the counterpart of majāz. After Abū 'Ubayda, al-Jāhiz (d. 869) contributed to the development of the theory by describing the contrast between haqīqa and majāz. ${ }^{26}$ Because of al-Jāhiz's contribution, Ibn Qutayba (d. 889) was able to point clearly to haqiqa as the opposite of majāz, and introduced majāz as 'way of saying' ( similar to Abū 'Ubayda) and as the counterpart of haqīqa. Also, Ibn Qutayba is known to be the first to set apart a chapter for majāz and isti 'âra, which is one of the essential subcategories of majāz. ${ }^{27}$

After al-Jāhiz, one of the major contributions to the theory of majāz was made in the $11^{\text {th }}$ century by 'Abd al-Qāhir al-Jurjānī (d. 1078 or 1081) with his two works Asrār al-Balāgha (The Mysteries of Eloquence) and Dalā'il al-'ijāz (Proofs

21 Wolfhart Heinrichs, "On the Genesis of the Haqīqa-Majāz Dichotomy," Studia Islamica, Maisonneuve \& Larose, no. 59 (1984): 112.

22 Oliveri, "Early Arabic grammar", 66-7.

23 Mustafa Shah, "The Philological Endeavours of the Early Arabic Linguists: Theological Implications of the tawqf-iil Antithesis and the majz Controversy/Part 1', Journal of Qur'anic Studies," Edinburgh University Press 1, no. 1 (2002): 28.

24 Muhammad Fuad Sezgin, Abū 'Ubayda. Majāz al-Qur'ān (Cario: Maktabat al-Khānj̄̄, 1954), 8; Heinrichs, “On the Genesis”, 119; Adem Yerinde, "Mecâz'ul Kur'ân'1 Cercevesinde Ebû Ubeyde'nin Tefsirciligi,” Sakarya Üniversitesi Illahiyat Fakültesi Dergisi, no.19 (2009): 151-189.

25 John Wansburgh, “Majaz al-Quran: Periphrastic exegesis,” BSOAS, no. 33 (1970): 248.

26 Ahmad Sakhr Achtar, "Contact between theology, hermeneutics and literary theory: The role of majäz in the interpretation of anthropomorphic verses in the Qur' $\overline{\text { an }}$ from $2^{\text {nd }} A H / 8^{\text {th }} C E$ until the $7^{\text {th }} A h / 13^{\text {th }} C E$ " (PhD diss., SOAS University of London, 2012), 60-66.

27 Achtar, "Contact between theology," 154; Selim Türcan, "Mecâz Teriminin Gelisim Surecinde el-Ferrâ'nın Yeri," Gazi Üniversitesi Çorum İlahiyat Fakültesi Dergisi 2, no. 4 (2003): 89-93; İsmail Aydın, "Hakikat ve Mecaz'ın Terimleşme Süreci," İslami İlimler Dergisi 8, no. 1 (Bahar 2013): 23-29. 
of Inimitability). ${ }^{28} \mathrm{He}$ offered a new dichotomy for the theory, which is majāz allughawi (a single word used beyond its conventional meaning) and majāz al- 'aqlī or h̆ukmī (which occurs in the sentence).$^{29}$ Al-Jurjānī's other important contribution to the concept of maja $\bar{a}$, and in particular to isti 'âra (metaphor), is his attribution to the immediate relation, or possibly blending between two mental images. ${ }^{30}$ There is no tangible evidence that shows whether al-Jurjānī directly influenced the legal theorists. Also, Ibn Malak in his work gives place to the views of the linguists to explain the divergence between legal theorists and linguists. Accordingly, it can be certainly argued that some of the legal theorists were aware of the relation between mind and majāz, and they incorporated this relation into the discussion in legal theory works.

\section{What is Majāz?}

Terminologically, majāz means 'to go beyond something'. It is a verbal noun formed from jāza: al-kalimatu al-jā' 'izatu ay al-mut 'aaddiyatu makānahāal- 'aliyya, "a word that goes beyond its original place (i.e. its literal meaning in the language system)" "31. Sayyid Sharīf al-Jurjānī describes majāz as:

Ismun lammā urīda bihī ghayr mā wuḍia ' lahū li munāsabatin baynahumā. ${ }^{32}$

A word that is intended to use in a different meaning- rather than its original/primordial assigned meaning, due to relationship/link/connection/analogy (munāsaba) between the two [humā $].{ }^{33}$

Isti 'âra ${ }^{34}$ literally means "borrowing" and corresponds to figure of speech or mode of expression. Although being one of the sub-categories of majāz, isti 'āra has its own demarcation; which is "[i]n the given context means borrowing the

28 Leezenberg, Contexts of Metaphor, 43-4; Soner Gündüzöz, "Klâsik ve Modern Arap Literatürü Açısından İslam Düşüncesinde Hakikat ve Mecaz Tartışmaları,” İslami İlimler Dergisi 8, no. 1 (Spring 2013): 32.

29 Sedat Şensoy, "Belağat Geleneğinde Aklî Mecâz Tartışmaları," İslam Araştırmaları Dergisi, no.8 (1986): 1-37; Simon, "Majāz," 117; Modaressi, "Some Recent Analyses," 788; Abdülkâhir El-Cürcânî, Delâilü 'l-I'câz, trans. Osman Güman (Istanbul: Litera Yayınevi, 2008), 257-61.

30 Simon, "Majāz," 118; Simon, "Isti 'āra," 442; Deeb, "Al-Jurjān̄̄," 62-3.

31 Simon, "Majāz," 116.

32 Sayyid Sharīf al-Jurjānī, Mu 'jam al-Ta 'rîfāt, ed. Muhammad Șiddīq al-Minshāwī (Qāhira: Dār al-fạ̣ila, 1982), 169.

33 Most of the quotations from the original text are translated into English by the author of the article, otherwise the name of the translator are given in the footnotes.

34 In Arabic linguistics, the comparison in isti 'âra is not necessarily confined with the relationship between genus and species, or the combination of tenor and vehicle (Simon, "Isti 'âra," 441-2). Nor is isti 'ära explained as a fundamental means for rhetoric. 
name or an attribute of something to stand for something else". ${ }^{35}$ This borrowing can occur in various forms and modes.

At the core of the idea that a word is used beyond its assigned meaning or that a meaning is borrowed, lies the concept of wad'. Wad' as a linguistics term became a key term in legal theories. For instance, in the $u s ̣ \bar{u} l$ of al-Dabusî, al-Bazdawî and al-Sarakhsī, wad ' appears as an important constituent. ${ }^{36} \mathrm{Wad}^{\text {' }}$ refers to a knowledge coming from the combination of lexicon, grammar, semantics, and dhihn. Literally taken, wad' means establishing, assigning. As a linguistic term, wad' is assigning meaning to vocals (lafz), in Bernard Weiss words, it is "a sort of name-giving". ${ }^{37}$ Wad ' is one of the key concepts for Arabic linguistics and the philosophy of language. The Mutazilī legal theorist 'Abbād b. Sulaymān (d. 864) states that "there is an inevitable relationship between lafž/vocable and $m a$ ' $n \bar{a}$ / meaning so that each vocable naturally signifies (dalāla) to wad 'its primordial meaning". ${ }^{38}$ In the definition above, wad' simply refers to the established or assigned primordial of a word, which is haqīqa. So, majāz and isti 'āra are a sort of assigning a second meaning, which is temporarily related to the lafz. For instance, assigning the "lion" to a lafz. And, ghayr mā wudi 'a lahu signifies the use for a second assigned meaning, which is the brave man, i.e. maja $\bar{z}$.

According to al-Jurjānī, during this process, dhihn is operative. In Abu Deeb's words, in the process of isti 'âra, it is "borrowing the meaning or the attribute of an object to be attributed to another object... it is essential that the meaning should be present in the mind of when isti 'âra is formed". ${ }^{39}$ To explicate, as in the example "Zayd is a lion", the temporarily borrowed attribute from lion to Zayd is the brevity. Out of its context, the lion indicates again its primary assigned meaning in the outside world, which is the animal. As to al-Jurjānī's argument, the mental content that relates brevity to a lion does already exist in the mind. This existing relation in mind leads to a second meaning assignation. In addition to al-Jurjān̄̄, we can also see that the legal theorists refer to operative function of dhihn while explaining the same example. However, the most intriguing point is that the legal theorists employ a set of terminology while explaining metaphoric structures related to legal

35 Simon, "Isti 'āra," 441.

36 Özdemir, Vaz’'Ilmi, 168-9.

37 Bernard Weiss, “'Ilm al-waḍ': An Introductory Account of a Later Muslim Philological Science," Arabica, no. 3 (November/1987): 342.

38 Hakime Reyyan Yaşar, "Marriage, Metaphor, and Law: Exploring Wive's Anomalous Legal Status in the Classical Islamic Marriage Contract" (PhD diss., School of Advanced Studies, University of London, 2018), 274; Özdemir, Vaz' İlmi, 37.

Deeb, “Al-Jurjānī,” 68/n. 3. 
provisions. This terminology used in order to explain the relationship between maja $\bar{z}$ and dhihn differs notably than al-Jurjānī- as it will be displayed below.

\section{Majāz in Ușül al-fiqh}

After the $10^{\text {th }}$ century, in parallel with the development of Ilm al-Balägha, maja $z$ emerged as an individual sub-heading in legal theories. ${ }^{40}$ Whilst the legal theory certainly obtains some linguistic aspects from 'ilm al-Balägha, there is also a considerable difference between them in terms of engaging in majāz and isti 'âra. Two major differences can be observed while reading the chapter of majāz in Hanafi legal theories. One of them is the way the legal scholars used both concepts, and the other is the purpose of analysing figurative speech.

For 'ilm al-Balägha, isti' $\bar{a} r a$ is one of the subcategories of majāz, due to the inclusive feature of majāz. As al-Jurjānī put in words: Majāz is a larger category than isti 'âra/metaphor ... [namely] every isti' 'ara is majāz, but not every majāz is isti 'âra $a^{41}$. Besides, in Hanafì ușül al-fiqh, isti 'âra is not openly discussed as the subcategory of majāz. Namely, the legal theorists used both terms synonymously/ interchangeably (mutarädifan). ${ }^{42}$ Another difference, and also the essential one, between the legal theorists and the other disciplines, is the purpose of analysing majāz. 'Ilm al-Balāgha propounds a theoretical analysis of majāz in language with aesthetic and linguistic concerns. By contrast, the legal jurists analyse majāz for legal interpretation and use majāz for legal decision-making, which means they are not interested in the artistic or the linguistic debates. According to them, majāz is using (isti ' $m \bar{a} l)$ a word beyond its primordial meaning.

Apart from being a tool for embellishment in language, majāz are also used to fill the semantic lacuna caused by the semantic deficiency of literal meaning in conveying the intended meaning. That is to say, maja $z$ is used if a semantic extension $\left(i t t i s \underline{a}{ }^{2}\right)$ is required ${ }^{43}$ Semantic extension, for the legal scholars, does not function only with aesthetic and creative purposes, but also it can carry with

40 Wolfhart Heinrichs, "On the figurative (majāz) in Muslim interpretation and legal hermeneutics," in Interpreting Scriptures in Judaism, Christianity and Islam: Overlapping Inquiries, eds. Mordechai Z. Cohen and Adele Berlin (Cambridge: Cambridge University Press, 2016), 249.

41 'Abd al-Qāhir 'Abd al-raḥmān b. Muḥammad al-Jurjān̄̄, Kitāb Asār al-Balāgha, ed. Maḥmūd Muḥammad Shākir (Jiddah: Dār al-madan̄i, 1991), 398. Translation quoted from Lara Harb (Lara Harb, "Form, Content, and the Inimitability of the Qur'an in 'Abd al-Qāhir al-Jurjān̄̄'s Works," Middle Eastern Literatures 18, no. 3 (2015): 309).

42 Ibn Malak, Sharh al-Manār wa Hawashiyya min 'ilm al-ușūl (Istanbul: Othmāniyya Matbaası, 1898), 399-400.

43 Görgün, Ușūl al-Fiqh, 132-37; Muḥammad bin Abu Sạ̣l Aḥmad al-Sarakhsī, Ușūl al- Sarakhsī, ed. Abu al-Wafā al-Afghānī (Dār al-Kutub al-'ilmiyya: Beirut, 1993), 1: 171. 
it the extension of the provisions. The legal theorists focused on explaining the mechanism of majāz to extend provisions and how an utterer uses maja $z$ in practice. These have been given by examples such as in oaths, words used in concluding commercial contracts, in a marriage contract, in manumission, and in divorce.

\section{Exploring Majäz in the Hanafĩ Legal Theory}

Little from the early Hanafi sources have survived to our time. To our knowledge, Abū Bakr Aḥmad b. 'Alī al-Rāḍī al-Jașșāṣ’s's (d. 981) uṣūl 'al-fușūlfì al- uṣūl' is one of the significant sources that introduce a complete work of Hanafì ușül al-fiqh. ${ }^{44}$ Al-Jașșāṣ in his work defines majāz as follows:

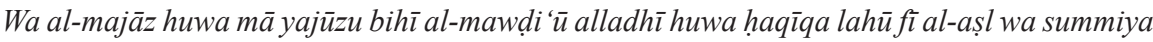
bihī mā laysa al-ism lahū haqīqa ${ }^{45}$

Majāz is a word, which is assigned to its original meaning, i.e. haqiqqa, and (later) is named for another name which is not [used] by its lexical [meaning] (haqiqa)'.

Al-Sarakhsī, the follower of al-Jașșās articulates in another explanatory definition for majāz that majāz is "a meaning that transits or moves (ta 'diyya) from its original meaning to another meaning" ${ }^{46}$ For instance, "the lion is coming". Here, the word "lion" moved from the primordial assigned meaning to express "brevity, courage".

With respect to isti 'âra, al-Sarakhsī describes it as: "each vocable that is borrowed (musta 'a $r$ ) for a thing [a meaning] in order to [be used] beyond its primordial assigned meaning". Then, he continues by stating "it [isti 'āra] is named majāz, because it is used beyond its originally (al-așl) assigned meaning $\left(a l-m a w d \bar{u}^{6}\right) "{ }^{47}$ As stated before, the Hanafì legal theorists use majāz and isti ' $\bar{a} r a$ alternately. ${ }^{48}$ This alternate employment creates a complicated affinity in the definition. Ibn Malak also expounds the reason why in some cases majāz was used instead of isti 'âra. He reasons by referring to the similarity in the creation of figurative speech, which is using a word beyond its primordial meaning. ${ }^{49}$ After describing majāz, the legal theorists suggest that both types are put in operation via the means "ittișăl (link,

44 Murteza Bedir, "al-Jașșāṣ (d. 370/981)," in Islamic Legal Thought A Compendium of Muslim Jurists, eds. Oussama Arabi, David S. Powers and Susan A. Spectorsky (Leiden-Boston: Brill Publishing, 2013), 153.

45 Ahmad ibn 'Alī al-Jaș̣āạ, Ușūl al-fiqh al-musammā bi al-Fuṣūl fì al-ușūl, ed. 'Ujayl Jāsim Nashamī, $2^{\text {nd }}$ ed. (al-Kuwayt: Wizārat al-Awqāf wa-al-Shu'ūn al-Islāmīyah, 1994), 1:361.

46 Al-Sarakhsī, Ușūl, 1:170.

47 Al-Sarakhsī, Ușūl , 1:170.

48 Wolfhart Heinrichs, The Hand of the Northwind: Opinions on Metaphor and the Early Meaning of Isti 'âra in Arabic Poetics (Wiesbaden: Kommisionsverlag franz Steiner GMBH, 1977), 26, 30.

Ibn Malak, Ușūl, 399. 
connection)". To explain this suggestion, the Hanafĩ scholars introduce a precise formulation: tarīq al-isti 'âra 'inda al- 'arab al-ittișāl-50 which means: the tool that establishes metaphor is ittișāl. Now, we will closely examine, what ittișāl is and how they related majāz to dhihn/mind.

\section{Ittisâā: The means that constitutes isti' ${ }^{\top} \bar{r} r$ /metaphor}

Ittis $\bar{a} l$ is derivated from the root $w-s-l$, and lexically means to connect, to establish a relation, a link, interlock and verbindung. In legal theory, the function of "ittisāal" varies depending on the focus of the subject. In the context of juristic analogy (qiy $\bar{a} s$ ), ittișa $\bar{l}$ is one of the means that leads to/causes the legal decision. Within the limits of majāz, al-ittișāl is used as a term explaining the mechanism for metaphors. That means, metaphors result by a sort of association (al-'alāqa, al-munāsaba).

As stated in the beginning, this study focuses on the linguistic dimension of the legal theory. Therefore, we will mainly evaluate ittișāl, in particular ittișāl al-ma 'nāwwi, from the scope of linguistics. In majāz, two functions are central to ittișāl. The first one is the expressive function, which has the major role (the linguistic aspect) and where two ideas are connected to express the intended meaning: for instance literary expressions or metaphors in the ordinary language. The other one is the legal functionpredominantly used by the legal scholars to extend a provision (sabab-musabbab). ${ }^{51}$

To start with, legal theorists categorise ittișāl into two: al-ittiṣāl bayna alshay 'ayni yakūn șüratan 'aw ma 'nan/the link between two things is originated by image or by ma ' $n \bar{a}$ (thought, mental, abstract, prediction) ". ${ }^{52}$ Al-Sarakhsī claims that there is an interaction between two things that constitutes metaphor. Although, al-Sarakhsī defines isti 'âra by a borrowing process between two words (lafz), here, intriguingly, he uses the word "al-shay "ayn (two things)" instead of "lafz (word, form)". According to this preference, the link or the transfer of the meaning does not occur merely between words, but between two things. Al-Sarakhsī does not feel the need to explain what he means with the "two things", which also connotes that al-shay'ayn is open to interpretation. Herewith, the problem of how al-shay'ayn should be understood arises. One might argue that al-shay 'ayn is used randomly. But then one may question: why did Bazdawī, who lived at the same century, similar to al-Sarakhsī, use the word al-shay 'ayn, instead of lafž/word -which is the key element for metaphor? ${ }^{53}$

50 Al-Sarakhsī, Ușūl, 1:178; Ibn Malak, Ușūl, 400.

51 Al-Sarakhsī, Ușūl, 1:180.

52 Al- Sarakhsī, Ușūl, 1:178; Ibn Malak, Ușūl, 399- 400.

53 Al-Sarakhsī, Ușūl, 1:178; Husām al-dīn Husein bin Alī bin Hajjāj al-Sighnākī, Al-Käfí al-sharh al-bazdawī, ed. Fakhr al-Dīn Sayyid Muhammad Qānit (Riyād: Maktabatu al-Rushd, 2001), 777. 
Intriguingly, Ibn Malak, who refers to al-Sarakhsī a lot, does not only content himself with the use of al-shay 'ayn but also tries to understand how this interaction occurs between these two things. Ibn Malak explains that the process between the two things or words occurs by a transfer between genus and species, or between two species, and on the other hand between $s a b a b$ and masbūb, or by comparison..$^{54}$ In this explanation, Ibn Malak tries to outline what is said about majāz before him in the Hanafî legal theories. However, his particularity does not result from this outline, rather how he implicates the role of mind/dhihn in this subject. He openly uses the word "al-dhihn" to express the determining factor in the transfer from genus to species, al-ittis āl and other types of figurative use. ${ }^{55} \mathrm{Ibn}$ Malak, where he discusses the boarders of maja $\bar{z}$, draws the attention to the fact that that majāz is a way of expressing the meaning not only by the means of lexical item, but more by the means of al-dhihn. ${ }^{56}$ According to him, this also means, both ittișāl and al-shay'ayn are related to mind and thought.

With this statement, Ibn Malak both expounds al-Sarakhsî's work and also diverges from Aristotle's metaphor. Furthermore, unlike al-Sarakhsī, Ibn Malak, does not immure the idea of connection (ittișāl) in the frame of isti 'âra. Ibn Malak mainly extends this idea into the whole concept of majāz. This also means that as to Ibn Malak, dhihn/mind has a primary function in any type of figurative usage. ${ }^{57}$ Particularly, the function of mind comes into sight while the legal theorists present the types of ittișāl in the discussion on metaphor which are ittișāl al-șūri (a link based on image) or ittișāl al-ma 'nāwi (a predictive link, or non-physical similarity which is abstract, or a link that represents the purpose of $h u k m /$ legal decision).$^{58}$

54 Ibn Malak, Ușūl, 401.

55 Ibn Malak, Ușūl, 382.

56 Ibn Malak, Ușūl, 380.

57 Ibn Malak, Ușül, 371, 372. Additional wise, the function of mind or mental representation is not only noticed by Hanafî legal theorists, but also the Shafīi, Zarkashī in his work named Bahr al-Muhit, explicitly states that this link is part of the cognitive process ('alāqa dhihniyyah) (Muḥammad ibn Bahādur al-Zarkashī, al-Baḥr al-muhìt fì uṣūl al-fiqh, ed. 'Ān̄̄, 'Abd al-Qādir 'Abd Allāh, Ashqar 'Umar Sulaymān (al-Kuwayt : Wizārat al-Awqāf wa-al-Shu'ūn al-Islāmīyah, , $1^{\text {st }}$ Edition, 1992), 2:199).

58 Unal Yerlikaya translates ittișāl al-ma 'nāwī into Turkish as connection based on purpose or function (amaçsal ilişski) (Ünal Yerlikaya, "Hanafî̀ Düşüncede Hakîkat-Mecâz İlişkisinin Kavranış Biçimine Etkisi Bakımından Sebep-İllet-Hüküm İlişkisi," Süleyman Demirel Üniversitesi Sosyal Bilimler Enstitüsü Dergisi 1, n. 30 (2018): 50). Here, I differ from Yerlikaya. In Islamic legal theory, ittișa $\bar{l}$ is designated as a means both for reaching hukm and for explaining metaphor. Therefore, the function of ittișāl al-ma 'nāwi varies depending on which purpose it is used and on the context. In relation to the focus of this article, I employ ma 'nāwi in the linguistic framework where it indicates an abstract and mental concept. 


\section{Ittiṣāl al-șūrū}

To start with ittișāl al-șūrì (image-based link), this link is established on the experience of the physical world or of that can be perceived by human senses $(m a h s \bar{u} s)^{59,60}$ Ittișāl al-șurri is the category to which the legal theorists allocate space to explain how they reach legal decisions, in comparison to ittișăl al-ma 'nāwwi.

One of the main examples given in the Hanafi texts is the expression "aw lämastum al-nis $\bar{a}$ " in Q 4: 43. The word lämasa (to touch) in the above ayah can convey two meanings: the literal meaning 'to touch' and the metaphoric meaning 'sexual intercourse'. A Shāfi'ī scholar in the classical period would translate this expression literally "do not touch". In the meanwhile, this expression can be understood figuratively- as the Hanafi tradition did and can be translated as "intercourse". For centuries, Hanafī and Shāfí'i legal schools separately embraced both the meanings of intercourse and touch. Here, the two legal schools, Hanafĩ and Shafi ${ }^{'} \overline{1}$, are in dispute as to whether lämasa in this context is majāz or not. Hanafites argue that, given the context of this ayah and the relevant hadith ${ }^{61}$, the word means "sexual intercourse". This dispute has practical consequences as well as legal. However, apart from the textual indications and interpretational choices, the essential point in this example is that the Hanafĩ scholars assume that there is an image-based link between "touching" and "intercourse", which is perceptible through senses (al-mahssūs). ${ }^{62}$ As the Hanafĩ scholars use the image-based closeness

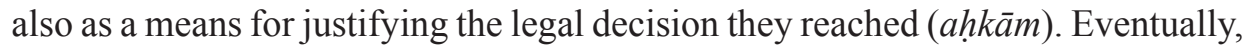
this link enables the jurists to engage this expression metaphorically and to extend the provision.

\section{Ittișāl al-ma'nāw}

With respect to ittișāl al-ma 'nāwwi (abstract and predictive link or a link established due to a shared legal purpose), the process of this link is different than the former. As explained before, this particular link has two functions: one in the juristic analogy (qiyass) and the second one in ordinary metaphors. This article is aimed at analysing the latter function of ittișāl al-ma 'nāwì , i.e. the linguistic dimension.

59 Al-Jurjānī in his Asrār al-Balāgha mentions three types of isti 'âra which two of them are based on image similarity and the third one based on abstract meaning. It is essential to note that the terminology used by al-Jurjānī notably differs from the Hanafī legal theorists. Ittișăl, which is a term in the Hanafĩ discourse, is hardly used. Al-Jurjānī has his own terminology to explain isti 'āra based image and on abstraction. For further information see: al-Jurjān̄i, 'Asāar al-Balāgha, 66,67, 74; Deeb, “al-Jurjānī,” 70-71.

60 Al-Sarakhsī, Ușūl, 1: 178.

61 Al-Sighnākī, Ușūl, 769-70.

62 Al-Sarakhsī, Ușūl, 1:178. 
The example for the ittișāl al-ma 'nāwì is the formulaic metaphor "Zaydun asadun" (Zayd is a lion). According to the native Arabic speaker and the target, there is a link between the lion and Zayd in terms of being strong and brave (ma ' $n \bar{a})$. This relationship does not stem from an observable similarity, since there is not a common space to compare a human being to a lion. But it is acknowledged that there is a shared meaning between them in terms of brevity. Similar to the example of the lion, the metaphor "the donkey is coming" is also given by the legal theorists. ${ }^{63} \mathrm{In}$ this metaphor, the donkey, as an animal, is associated with being dull or stupid. The reason for this association cannot be sensed or justified by claiming for an observable similarity. Therefore, the jurists called this semantic shared domain "ma "nawi (an abstract and predictive relationship", because the so-called shared domain is an outcome of prediction or assumption. ${ }^{64}$

This link is based on mental representations which have an important role in creating this link. While explaining this particular link in the Ușül, unfortunately, the legal theorists analyse only one or two examples, which are mostly formulaic. To clarify what the legal theorists meant with this link, I will draw upon Ibn Malak and al-Sighnāqī's works. There are two crucial points in their analysis to this example. One of them is the idea that the link is not between two words, but mahal (domain), which is an abstract concept rather than a physical space. And the second is the idea of composing a similarity between two completely distinctive things in the mind of the speaker. As mentioned before, Ibn Malak states that it is al-dhihn which transfers the second assigned meaning to the metaphor (wa al-murād 'an yakūn al-ma 'nā al-waḍi 'yyu bi haythu yantaqil min hu al-dhihn ilā al-ma 'nā al-majāziyyi ${ }^{65}$ ). For instance, between stupidity (balīd) and donkey (himāor), there is no essential similarity and familiarity between them. Despite this, it is assumed that there is a shared semantic domain between stupidity and donkey.

So, there is neither physically, biologically, nor lexically, an observable link between "lion and Zayd" and "stupidity and donkey" in the outside world. This link exists in the mind of the utterer and the target. Bazdawi expresses the exigency of the link between the two concepts as: "tarīq al-isti 'ära 'inda al-'arab al-ittișâl bayna al-shay'ayn" "66, i.e. metaphor is composed as a result of the link between two things. Then, al-Sighnāqī in his annotation to Bazdawī's legal theory interprets what those two things can be. By utilising from linguistic terminology, al-Sighnāqī states

63 Al-Sighnākī, Ușūl, 778.

64 Simon, "Isti 'āra," 442.

65 Ibn Malak, Ușūl, 409.

66 Al-Sighnākī, Ușūl, 777. 
that these two things are indeed al-musta' $\bar{a} r$ 'anhu (from which the metaphoric meaning is borrowed) and al-musta 'âr lah (that to which the borrowed meaning is given) ${ }^{67}$. In another discussion in the same work, he again recalls the same metaphor and claims that the Arabs see a specific shared ma ' $n \bar{a}$ (shared semantic entity) between Zayd and lion. ${ }^{68}$ But, this shared semantic entity cannot be sensed, as it has no reflection in the physical world. Later, in a proceeding topic, he states that ittișāl occurs between the domain of majāz and domain of haqīqa (wa al-ittișāl bayna mahal al-majāz wa bayna al-haqīqa ${ }^{69}$. Here, al-Sighnāqī does not seem interested in qualifying what these two things are and what kind of mechanism relates these two things or what he means with "mahal". Nor does he notice how he looks from many different perspectives to the expression "al-shay'ayn".

Another remarkable discussion in the text paving the way to comprehend the two things is on whether ittișa $l$ is an association or comparison occurring between all aspects of the compared entities, or whether we can only talk about a correlation of specific domains in metaphor. ${ }^{70}$ As explained before, isti 'ära is a result of an interaction between two particular domains. The Hanafì legal theorists argue that one of the major features of isti 'âra is that there is only a partial link. Ibn Malak explains what kind of theoretical and practical effect the partial and complete link has. He states that if the association occurs between all aspects, it is reasoning ('illa)that belongs mainly to the domain of juristic analogy (qiy $\bar{a} s$ ), and if the association occurs partially, it is a cause (sabab)- functions in the metaphoric analogy. ${ }^{71}$ To expand on this, the important point is that the link between Zayd and the lion is only carried out in terms of bravery, with all other characteristics of a lion being ignored. Namely, the relationship between Zayd and lion can be activated only by the shared semantic area ( $m a$ ' $n \bar{a})$ that is known by its linguistic community.

Up to now, we have presented how the Hanafĩ legal scholars explained the mechanism of majāz and the relation of mind to majāz. In the course of the explanation, they used particular terms and concepts, and these are ittișa $\bar{l}$, aldhihn, ittișāl al-șūrī, ittișāl al-ma 'nāwī, al-shay'ayn, and al-mahal. Based upon the terminology and the categorisation of ittișa $l$, it can be easily said that the Hanafi scholars were aware of the operative function of mind in maja $z$ and some cognitive elements can be found in the Hanafi legal theories. However, it is essential to

67 Al-Sighnākī, Ușūl, 777.

68 Al-Sighnākī, Ușūl, 801.

69 Al-Sighnākī, Ușūl, 821.

70 Al-Sighnākī, Ușūl, 801.

71 Ibn Malak, Ușūl, 400. 
consider Al-Karaki's remark on the pitfall of juxtaposing cognition in the Arabic philosophy of language with contemporary cognitive theory to metaphor. The contemporary approaches to metaphor theories today has dedicated itself to explore the intriguing relationship between cognition and metaphor. But what does cognition mean in contemporary terms and how does it operate in metaphor construction?

In the $20^{\text {th }}$ century, I. A. Richards (1936), with the interest to understand and explore the mechanism of metaphor, introduced his own approach and a set of useful terms. ${ }^{72}$ In his approach, Richards first developed the idea of "transference from genus to genus, from genus to species, from species to species or analogy", into the idea of that each metaphor consists of two parts: tenor and vehicle. In metaphor, tenor (Latin for connection) represents a person, place or thing, and vehicle is what tenor represents. In this approach, metaphor was no longer reduced in a passive theory of words or substitution; but rather, it is an active "interaction" between "tenor" and "vehicle". 73

Later, in the 1960's, Max Black lays another brick on Richards's views by suggesting that the concept of interaction between these two parts should be qualified. Black argues that there is a constructed commonplace where the interaction takes place in the semantic area. For instance, in the semantic area of Zayd and lion (brevity). In his theory, the idea of "interaction of commonplaces" takes place in the semantic area of the language, and through words. ${ }^{74}$ Recent experimental results from cognitive linguistics prove that interaction, mappings, and creating relation are the key functions for the mechanism of metaphor. ${ }^{75}$ Fauconnier and Turner provide a rich and deep understanding of the process of this mapping that underlies the way we think and how we relate concepts to the metaphor. Meaning giving for metaphor occurs by understanding one experience in terms of another experience through an analogical process.

72 Andrew Ortony, "Metaphor, language and thought" in Metaphor and Thought, ed. Andrew Ortony, $2^{\text {nd }}$ Edition (Cambridge: University of Cambridge Press, 1993), 3.

73 Miriam Taverniers, Metaphor and metaphorology A selective genealogy of philosophical and linguistic conceptions of metaphor from Aristotle to the 1990s (Belgium: Academia Press, 2002), 21.

74 Max Black, "Metaphor," Proceedings of the Aristotelian Society, New Series, no.55 (1954-1955): 273-294. Max Black, "More about Metaphor," in Metaphor and Thought, ed. Andrew Ortony, $2^{\text {nd }}$ Edition (Cambridge, New York, Melbourne: Cambridge University Press, 1993), 21.

75 George Lakoff, "The Contemporary theory of metaphor," in Metaphor and Thought, ed. Andrew Ortony, $2^{\text {nd }}$ Edition, (Cambridge, New York, Melbourne: Cambridge University Press, 1993), 203; Gilles, Fauconnier and Mark Turner, The Way We Think: Conceptual Blending and the Mind's Hidden Complexities (New York: Basic Books, 2002), 39-57, 278-308; Gilles Fauconnier, Mappings in Thought and Language (Cambridge: University of Cambridge Press, 1997), 127-30. 
Fauconnier extends this analogical process by introducing various examples showing how this process works. For instance, the word journey calls to mind a situation by which physical motion from one place to another occurs. At the same time, one might also notice that journey is used to refer to one's experience for state of mind. For instance, Love is a journey. In the example of journey, while uttering the metaphor, a mapping occurs between the two conceptual domains ${ }^{76}$, namely between the abstract experience (such as love) (target domain) and the concept of journey which is more a physical activity (source domain). Lakoff and Johnson call it the conceptualisation of metaphors; where one concept/ domain is understood in terms of another concept/ domain. ${ }^{77}$ By introducing new useful terms to explain how metaphors operate, Richards, Black and Lakoff and Johnson drift apart from Aristotle's definition of metaphor. Here, we tried to present a small fraction of what kind of concepts and terminology is used today while explaining how the mind operates while using metaphors. Saliently, it can be argued that both majāz in Hanafi ușūl al-fiqh and the contemporary approach to metaphor has digressed from Aristotle's definition of metaphor and both have introduced their own terminology to articulate the formulation of metaphor- where dhihn/mind/ cognition has its own room in these discussions.

\section{Conclusion}

In this article, we have sought to demonstrate the linguistic dimension of Islamic legal theory by focusing on the subject of majāz in Hanafì ușūl al-fiqh. In particular, it is briefly pointed out, the relationship between maj $\bar{a} z$ and mind and the cognitive elements mentioned in the legal theories. To discuss the argument of this article on solid ground, we have chosen to focus on the terms ittișāl, șürī, ma 'nāa, dhihn, and mahal.

The Hanafì legal scholars argue that majāz and isti 'âra are constituted via a particular link named ittișăl. Ittișāl operates in two different types and processes which are ittișăl al-șūrì and ittișāl al-ma 'nāwwi. These types explain the relationship between the two different semantic entities that generate figurative expression. Namely, 'making something belong to something else' through claiming a similarity ( $\left.m a^{\prime} n \bar{a}\right)$ or image-based similarity $(s \bar{u} r \bar{\imath})$. As Ibn Malak clearly put forwards, in this process the mind is operative. Namely, ittișāl al-șūr links two semantic domains by relying on a shared common ground that can be sensed or that can be observed in the physical world. In ittișall al-ma 'nāwì , it is presumed that there is a shared common ground between two semantic domains.

76 Lakoff, "Metaphor," 211-13.

77 George Lakoff and Mark Johnson, Metaphors We Live By With a New Afterword (Chicago and London: The University of Chicago Press, 2003), 17-21. 
On the side of Arabic linguistics, Simon and Leezenberg claim that while discussing majāz, al-Jurjānī refers to the cognitive content of majāz in his works. There are points to contemplate on this claim. One of them is, unfortunately, as noted by Al-Karaki, is to approach cautiously the term cognition in contemporary linguistic theories along with the conceptual field of dhihn in Arabo-Islamic linguistics- as modern use of cognition differs from traditional use of cognition (dhihn).

The recent studies dedicated to challenging the micro-characterisation of metaphor mainly confine metaphor in transfer, deviance of words and substitution. Instead of using the concepts and terms of Aristotelian metaphor, semantic domains, mapping, interaction, and physical world or conventionalized experience became the means that elaborate and explain the nature of metaphor. The cognitive-semantic theory of metaphor (by Lakoff and Johnson) place experience in the center of his theory and claim that metaphors function mostly in a conceptual system and metaphors are a matter of thought, rather than language.

Reflecting on these explanations of these Hanafi authors, it is not easy to argue that the legal theorists conceptualised cognition in the same way that contemporary metaphor theories do today. But, one can also not claim that the legal theorists approached majāz or isti 'āra secluded from any mental process or engaged majāz in a reduced form of transfer from genus to species or merely a comparison. Indeed, where the discussion on why genus is required for a metaphor takes place, Ibn Malak clearly articulates that genus is required so that al-dhihn (mind) can relate it to species. Furthermore, the function of cognition is underpinned by the categorization of ittișāl as image-based relation and relation based on prediction. This again demonstrates the way the Hanafĩ legal theorists understand the process of isti 'ära. The use of the expression al-shay 'ayn again is another matter to discuss. It can be claimed that the use of al-shay 'ayn refers to the two semantic domains. Unfortunately, the Hanafĩ works do not provide a well-developed theoretical background for us to understand the terminology used for majāz. However, there is terminology that enables us to explore and to interpret to what extent the mind is incorporated in the theory of majāz.

Peer-review: Externally peer-reviewed.

Conflict of Interest: The author has no conflict of interest to declare.

Grant Support: The author declared that this study has received no grant support. 


\section{References}

Abū 'Ubayda. Majāz al-Qur'ān. Edited by Muhammad Fuad Sezgin, Cario: Maktabat al-Khānjī, 1954.

Achtar, Ahmad, Sakhr. Contact between theology, hermeneutics and literary theory: The role of majāz in the interpretation of anthropomorphic verses in the Qur'an from $2^{\text {nd }} A H / 8^{\text {th }} C E$ until the $7^{\text {th }} A H / 13^{\text {th }} C E . "$ PhD diss., SOAS University of London, 2012.

Adamson, Peter and Key, Alexander. "Philosophy of Language in the Medieval Arabic Tradition." in Linguistic Content: New Essays on the History of Philosophy of Language, edited Margaret Camoran and Robert J. Stainton, 74-99. Oxford: Oxford University Press, 2015.

Al-Bukhārī, Abdalazīz. Kashf al-Asrār 'an Ușūl li Fahr al-Islām Bazdawī. Istanbul: Sahāfîye-i Osmāniyye Publishing, 1890-91.

Al-Jașșāṣ, Ahmad ibn 'Alī. Ușūl al-fiqh al-musammā bi al-Fuṣūl fì al-uṣūl. Edited by Nashamī, 'Ujayl Jāsim. $2^{\text {nd }}$ Edition. Al-Kuwayt: Wizārat al-Awqāf wa-al-Shu'ūn al-Islāmīyah, 1994.

Al-Jurjān̄̄, 'Abd al-Qāhir 'Abd al-raḥmān b. Muḥammad. Kitāb 'Asār al-Balāgha. Edited by Mạ̣mūd Muḥammad Shākir. Jiddah: Dār al-madan̄i, 1991.

Al-Jurjānī, Sayyid Sharīf. Mu 'jam al-Ta 'rīfāt, edited by Muhammad Șiddīq al-Minshāwī. Qāhira: Dār al-faḍila, 1982.

Al-Karaki, Balqis. "Dissimilar Premises, Similar Conclusions: On the Partial Rationality of Metaphora Comparative Study.” Journal of Near Eastern Studies 70, no. 1 (April 2011): 81-100.

Al-Sam‘ān̄̄, Manșūr ibn Muhammad. Qawāti 'al-adillah fì al-uṣūl. Edited by Muḥammad Ḥasan Muḥammad Ḥasan Ismā‘̄ill al-Shāfi'‘̂̉, Bayrūt: Dār al-Kutub al-'Ilmīyah, 1997.

Al-Sarakhsī, Muḥammad bin Abu Saḥl Aḥmad. Ușūl al-Sarakhsī. Edited by Abu al-Wafā al-Afghānī. Dār al-Kutub al-'ilmiyya: Beirut, 1993.

Al-Sighnākī, Husām al-dīn Husein bin Alī bin Hajjāj. Al-Kāfì al-sharh al-bazdawī. Edited by Fakhr al-Dīn Sayyid Muhammad Qānit. Riyād: Maktabatu al-Rushd, 2001.

Al-Zarkash̄̄, Muhammad ibn Bahādur. al-Bahr al-muḥ̂t fì uṣūl al-fiqh. Edited by 'Ān̄̄, 'Abd al-Qādir 'Abd Allāh, Ashqar 'Umar Sulaymān, ${ }^{\text {st }}$ Edition. Al-Kuwayt : Wizārat al-Awqāf wa-al-Shu'ūn al-Islāmīyah, 1992.

Aydın, İsmail. “Hakikat ve Mecaz'ın Terimleşme Süreci.” İslami İlimler Dergisi 8, no. 1 (Bahar 2013): 23-29.

Black, Max. "Metaphor." Proceedings of the Aristotelian Society, New Series, no. 55 (1954-1955): 273-294.

Black, Max. "More about Metaphor." in Metaphor and Thought, edited by Andrew Ortony, 19-41. Second Edition, Cambridge, New York, Melbourne: Cambridge University Press, 1993.

El-Cürcânî, Abdülkâhir. Delâilü'l-İ'câz. Translated by Osman Güman. Istanbul: Litera Yayınevi, 2008.

Fauconnier, Gilles, Turner, Mark. The Way We Think: Conceptual Blending and the Mind's Hidden Complexities. New York: Basic Books, 2002.

Fauconnier, Gilles. Mappings in Thought and Language. Cambridge: University of Cambridge Press, 1997.

Gemuhluoğlu, Zeynep. "İslâm Düşüncesine Özgü Bir Poetikadan Söz Edilebilir mi?: İlk Dönem Kelâm ve Dil Âlimlerinde Din Dili-Mecâz/Şiir-Mecâz İlişkisi Üzerine Bir İnceleme.” M. Ü. İlahiyat Fakültesi Dergisi 36, no.1 (2009): 109-134. 
Gibbs, Raymond, W. "When is Metaphor? The Idea of Understanding in Theories of Metaphor." Poetics Today, Aspects of Metaphor Comprehension 13, no.4 (Winter 1992): 575-606.

Görgün, Tahsin. Sprache, Handlung und Norm: Eine Untersuchung zu "Ușül al-Fiqh" und "Kitāb as-Siyar" des Šams al-A'imma Muhammad b. Abi Sahl Ahmad as-Sarahsi (1009-1090 n. C.). Istanbul: İSAM Yayınevi, 1998.

Gündüzöz, Soner. "Klâsik ve Modern Arap Literatürü Açısından İslam Düşüncesinde Hakikat ve Mecaz Tartışmaları.” İslami Ilimler Dergisi 8, no. 1 (Spring 2013): 31-46.

Harb, Lara. "Form, Content, and the Inimitability of the Qur'an in 'Abd al-Qahir al-Jurjānī’s Works." Middle Eastern Literatures 18, no. 3 (2015): 301-321.

Heinrichs, Wolfhart. "On the Genesis of the Haqiqa-Majāz Dichotomy." Studia Islamica, Maisonneuve \& Larose, no. 59 (1984): 111-140.

Heinrichs, Wolfhart. "On the figurative (majâz) in Muslim interpretation and legal hermeneutics." in Interpreting Scriptures in Judaism, Christianity and Islam: Overlapping Inquiries, edited by Mordechai Z. Cohen and Adele Berlin, 249-265. Cambridge: Cambridge University Press, 2016.

Heinrichs, Wolfhart. The Hand of the Northwind: Opinions on Metaphor and the Early Meaning of Isti 'âra in Arabic Poetics. Wiesbaden: Kommisionsverlag Franz Steiner GMBH, 1977.

Ibn Malak. Sharh al-Manār wa Hawashiyya min 'ilm al-uṣūl. Istanbul: Othmāniyya Matbaası, 1898.

Kalbarczyk, Nora. Sprachphilosophie in der Islamischen Rechtstheorie: Zu avicennischen Klasifikation der Bezeichnung bei Fah̆r ad-dīn ar-Rāzì. Leiden, Boston: Brill, 2018.

Kirby, John T. “Aristotle on Metaphor.” The American Journal of Philology 118, no.4 (Winter 1997): 517-554.

Lakoff, George \& Johnson, Mark. Metaphors We Live By With a New Afterword. Chicago and London: The University of Chicago Press, 2003.

Lakoff, George. "The Contemporary theory of metaphor." in Metaphor and Thought, edited by Andrew Ortony, 202-251. $2^{\text {nd }}$ Edition, Cambridge, New York, Melbourne: Cambridge University Press, 1993.

Leezenberg, Michiel. Contexts of Metaphor. 1st Edition. Oxford: Elsevier Science Ltd, 2001.

Levin, Samuel R. “Aristotle's Theory of Metaphor.” Philosophy \& Rhetoric 15, no. 1 (Winter 1982): 24-46.

Modaressi, Hossein. "Some Recent Analyses of the Concept of majāz in Islamic Jurisprudence." Journal of the American Oriental Society 106, no. 4 (Oct.-Dec. 1986): 787-791.

Murteza, Bedir. "Al-Jașșāṣ (d. 370/981)" in Islamic Legal Thought A Compendium of Muslim Jurists, edited by Oussama Arabi, David S. Powers and Susan A. Spectorsky, 147-166. Leiden-Boston: Brill Publishing, 2013.

Oliveri, Simona. "Early Arabic grammar: sources and codification." in Dal Medio all'Estremo Oriente, edited by Marina Miranda and Raffaele Torella e Mario Casari, 63-74. Roma: Carocci Editore, 2018.

Ortony, Andrew. "Metaphor, language and thought." in Metaphor and Thought, edited by Andrew Ortony, 1-16. $2^{\text {nd }}$ Edition, Cambridge: University of Cambridge Press, 1993.

Özdemir, Ibrahim. İslam Düşüncesinde Dil ve Varlık Vaz’İlminin Temel Meseleleri. Istanbul: İz Publishing, 2006.

Richards, I. A. Philosophy of Rhetoric. New York: Oxford University Press, 1965. 
Salama, Mohammad. The Qur'an and Modern Literary Critisim: From Taha to Nasr. London: Bloomsbury Academic/ Bloomsbury Publishing, 2018.

Şensoy, Sedat. "Belağat Geleneğinde Aklî Mecâz Tartışmaları (The Discussions about Majāz al- 'Aqlī in 'ilm al-Balāgha)." İslam Araştırmaları Dergisi, no. 8 (1986): 1-37.

Shah, Mustafa. "The Philological Endeavours of the Early Arabic Linguists: Theological Implications of the tawqf-iil Antithesis and the majaz Controversy/Part 1." Journal of Qur'anic Studies, Edinburgh University Press 1, no. 1 (2002): 43-66.

Simon, Udo. "Majâz.” Encyclopaedia of Arabic Language and Linguistics, Leiden: Brill, 2008.

Simon, Udo. "Isti‘âra." Encyclopaedia of Arabic Language and Linguistics, Leiden: Brill, 2008.

Taverniers, Miriam. Metaphor and metaphorology a selective genealogy of philosophical and linguistic conceptions of metaphor from Aristotle to the 1990s. Belgium: Academia Press, 2002.

Türcan, Selim. "Mecâz Teriminin Gelisim Surecinde el-Ferrâ'nın Yeri." Gazi Üniversitesi Çorum Illahiyat Fakültesi Dergisi 2, no. 4 (2003): 89-122.

Türker, Ömer. Seyyid Şerif Cürcani’nin Tevil Anlayışı: Yorumun Metafizik, Mantıki ve Dilbilimsel Temelleri. PhD diss., University of Marmara, 2006.

Vishanoff, David R. The Formation of Islamic Hermeneutics How Sunni Legal Theorist Imagined a Revealed Law. New Haven, Connecticut: American Oriental Society, 2011.

Wansbourgh, John. "Majaz al-Quran: Periphrastic exegesis.” BSOAS, no. 33 (1970): 247-66.

Weiss, Bernard. “'Ilm al-wad': An Introductory Account of a Later Muslim Philological Science." Arabica, no. 3 (November 1987): 339-356.

Yaşar, Hakime Reyyan. "Marriage, Metaphor, and Law: Exploring Wive's Anomalous Legal Status in the Classical Islamic Marriage Contract." PhD diss., School of Advanced Studies, University of London, 2018.

Yerinde, Adem. "Mecâz'ul Kur'ân'1 Çerçevesinde Ebû Ubeyde'nin Tefsirciliği." Sakarya Üniversitesi Ilahiyat Fakültesi Dergisi, no. 19 (2009): 151-189.

Yerlikaya, Ünal. "Hanafî Düşüncede Hakîkat-Mecâz İlişkisinin Kavranış Biçimine Etkisi Bakımından Sebep-İllet-Hüküm İlişkisi.” Sülayman Demirel Üniversitesi Sosyal Bilimler Enstitüsü Dergisi 1, no. 30 (2018): 48-70. 
